\title{
Lysine and Protein Metabolism in Young Women

\author{
Subdivision Based on the Novel Use of Multiple Stable Isotopic Labels
}

Charles S. Irving, M. Rita Thomas, Edward W. Malphus, Lisa Marks, William W. Wong, Thomas W. Boutton, and Peter D. Klein

U. S. Department of Agriculture/Agricultural Research Service, Children's Nutrition Research Center; Department of Pediatrics, Baylor College of Medicine and Texas Children's Hospital, Houston, Texas 77030

\begin{abstract}
A multitracer stable isotope study of lysine kinetics was carried out in fasted adult female volunteers to determine whether a multicompartmental model that partitions protein synthesis and breakdown into at least two types of tissue components can be constructed from plasma and breath data. Five female subjects, maintained on formula diets, received $L-{ }^{13} C_{1}$ llysine $(27 \mu \mathrm{mol} /$ $\mathrm{kg})$ as an i.v. bolus and $\mathrm{L}-\left[{ }^{15} \mathrm{~N}_{2}\right]$ lysine $(27 \mu \mathrm{mol} / \mathrm{kg})$ as an oral bolus $4 \mathrm{~h}$ postprandially. Plasma and breath samples were collected for $6 \mathrm{~h}$. On an alternate day, subjects received $\mathrm{NaH}^{13} \mathrm{CO}_{3}$ $(10 \mu \mathrm{mol} / \mathrm{kg})$ as an i.v. bolus and breath samples were collected for $6 \mathrm{~h}$. Plasma tracer lysine levels were determined by gas chromatography-mass spectrometry isotope ratiometry, and breath ${ }^{13} \mathrm{CO}_{2}$ levels were measured by mass spectrometric gas isotope ratiometry. The tracer data could be fitted to a mammillary multicompartmental model that consisted of a lysine central compartment and slow- and fast-exchanging peripheral compartments containing 37, 38, and $324 \mu \mathrm{mol} / \mathrm{kg}$, respectively. The rates of lysine oxidation, incorporation into protein, and release by protein breakdown were 21,35 , and $56 \mathrm{mmol} / \mathrm{kg} / \mathrm{h}$, respectively, in the fast-exchanging compartment, whereas the rates of protein synthesis and breakdown in the slow compartment were both $53 \mathrm{mmol} / \mathrm{kg} / \mathrm{min}$. These values corresponded to a whole-body lysine flux of $106 \mathrm{mmol} / \mathrm{kg} / \mathrm{h}$. The kinetic parameters were in excellent agreement with reported values obtained by constant-infusion methods. The measurements indicated that it will be possible to detect changes in amino acid pool sizes and protein synthesis and breakdown associated with the mobilization of protein stores from plasma and breath measurements in multitracer stable isotope experiments.
\end{abstract}

\section{Introduction}

Tracer studies of whole-body protein turnover in humans have characterized the alterations in whole-body protein synthesis and breakdown that account for the changes in nitrogen balance associated with reduced protein and energy intakes, trauma, sepsis, burns, and cancer $(1,2)$. Because whole-body protein turnover rates integrate the metabolism of all proteins throughout all body tissues, they cannot answer questions about the partitioning of amino acid pools and protein synthesis and breakdown in relation to body size, age, metabolic rate, meal ingestion, long-term dietary intake, or trauma. Tissue sampling $(3,4)$ and

Received for publication 10 December 1984 and in revised form 2 December 1985 .

J. Clin. Invest.

(c) The American Society for Clinical Investigation, Inc.

$0021-9738 / 86 / 04 / 1321 / 11 \quad \$ 1.00$

Volume 77, April 1986, 1321-1331 arteriovenous (5) catherization techniques, used extensively in animal studies to characterize protein metabolism in specific tissues, are not applied easily in human investigations (5-8). A noninvasive tracer method, based on plasma and breath sampling (9-11), that could resolve protein synthesis and breakdown in different body compartments in human subjects would facilitate the investigation of the mobilization of protein stores in response to nutritional, metabolic, and pathophysiologic challenges. A multitracer stable isotope study of lysine kinetics was carried out in fasted adult female subjects to determine whether it was possible to construct an identifiable multicompartmental model from plasma and breath isotopic data that could partition protein synthesis and breakdown into at least two different types of body compartments. We report the characteristics of the first multicompartmental model of lysine metabolism in humans, which includes resolution of protein synthesis and breakdown in two peripheral pools with properties that correspond to reported values of muscle and viscera, respectively.

\section{Methods}

Materials. $\mathrm{NaH}^{13} \mathrm{CO}_{3}$ (Merck Sharp \& Dohme Canada Ltd., Montreal, Quebec), which contained 90 atom percent excess (APE) ${ }^{1}{ }^{13} \mathrm{C}$ as assayed by gas isotope ratio-mass spectrometry, was made up at a concentration of $200 \mathrm{mM}$ in saline and sterilized by filtration. L-[ $\left.\operatorname{carboxyl}{ }^{13} \mathrm{C}\right]$ lysine/ $\mathrm{HCl}$ (Merck Sharp \& Dohme Canada Ltd.), which contained 99 APE ${ }^{13} \mathrm{C}$, was assayed by gas chromatography-mass spectrometry and made up to a concentration of $100 \mathrm{mg} / \mathrm{ml}$ in water. $\mathrm{L}-\left[{ }^{15} \mathrm{~N}_{2}\right] l y s i n e / \mathrm{HCl}(96$ APE ${ }^{15} \mathrm{~N}$ ) was prepared by microbial fermentation from ${ }^{15} \mathrm{NH}_{4} \mathrm{SO}_{4}(11)$ and purified before use. It was dissolved in Gatoraid (Stokely Van Camp, Minneapolis, $\mathrm{MN}$ ) immediately before ingestion. $\mathrm{D}_{\mathbf{8}}$-Lysine (Merck Sharp \& Dohme) contained 98 APE deuterium and was used as an internal standard in the analytical procedures without further purification. All solutions administered intravenously were tested for sterility and absence of pyrogens before use.

Subjects. Healthy, nulliparous, women (23-33 yr old), whose weights were within $95-120 \%$ of ideal body weight and whose diets included at least $50 \%$ of the recommended dietary allowances (12), were recruited into the study. The characteristics of the five subjects are given in Table I. Each subject underwent a physical examination and review of medical history. After a thorough explanation of the purpose of the study, the diet regimen, and the protocol for the kinetic measurements, informed consent was obtained from each subject. The study was approved by the Institutional Review Boards for Human Research of Baylor College of Medicine and Texas Children's Hospital.

Dietary intakes. Protein, carbohydrate, and fat dietary intakes prior to the study (Table II) were calculated from dietary histories. On day 1 of the study, subjects were placed on a Sustacal formula diet (Mead Johnson, Evansville, IN) designed to provide intakes of protein, carbohydrate, and fat composition (Table II) that approximated prestudy intakes. In addition to the liquid formula, fruits and vegetables were added to the diet up to the level of $5 \%$ of protein intake and $150-200 \mathrm{kcal} / \mathrm{d}$.

1. Abbreviations used in this paper: APE, atom percent excess. 
Table I. Physical Parameters of Women Participating in the Lysine Metabolism Study

\begin{tabular}{llll}
\hline Subjects & Age & Weight & Height \\
\hline & $y r$ & $k g$ & $\mathrm{~cm}$ \\
$\mathrm{C} 1$ & 33 & 58.2 & 160 \\
$\mathrm{C} 2$ & 31 & 51.8 & 165 \\
$\mathrm{C} 3$ & 30 & 52.3 & 160 \\
$\mathrm{C} 4$ & 26 & 65.9 & 175 \\
$\mathrm{C} 5$ & 23 & 66.8 & 171 \\
Mean \pm SD & $28.6 \pm 4.0$ & $59.0 \pm 7.2$ & $166 \pm 6.7$ \\
\hline
\end{tabular}

During the course of the 4-d study, intakes of liquid formula and foods were weighed and recorded. Subjects were asked to follow their normal daily routines during the study whenever possible.

Bicarbonate and lysine kinetic measurements were made on the mornings of days 2 and 3, respectively. $4 \mathrm{~h}$ before the bicarbonate and lysine kinetic measurements, subjects consumed a formula meal which provided $25 \%$ of their daily protein intake and $20 \%$ of their total energy intake. Except for decaffeinated, sugar-free beverages, subjects fasted for the next $10 \mathrm{~h}$. This feeding schedule for normal subjects was dictated by the length of fast that would be appropriate for breast-feeding mothers who would participate in subsequent studies.

Bicarbonate kinetic measurements. Kinetic studies were based on the protocol previously described by Irving et al. (13). For the first 60 min of the protocol, subjects wore a face mask fitted with two one-way valves. Respiratory volumes were measured over 2 -min periods with a respirometer attached to the inlet valve and samples of respiratory gas were collected for $\mathrm{CO}_{2}$ analysis only after respiratory volumes became reproducible. Thereafter, samples were collected at hourly intervals together with respiratory volume measurements. Samples of respiratory gas $(50 \mathrm{ml})$ for ${ }^{13} \mathrm{CO}_{2}$ analysis were collected at 30,15 , and $2 \mathrm{~min}$ before isotope injection and then at $0.25,0.5,0.75,1,2,3,5,7,10,15,20,30$, $45,60,90,120,150,180,240,300$, and 360 min thereafter. Subjects received an i.v. bolus dose of $10 \mu \mathrm{mol} / \mathrm{kg}$ of $\mathrm{NaH}^{13} \mathrm{CO}_{3}\left(90 \%{ }^{13} \mathrm{C}, 200\right.$ $\mathrm{mM}$ in water) into either the right or left arm antecubital vein.

Lysine kinetic measurements. Baseline breath samples were collected and respiratory volumes were measured as described above. A heparin lock for blood sampling was placed in the opposite arm from the injection site. Blood samples $(2 \mathrm{ml})$ were drawn immediately before and at 1,2 , $3,5,7,10,15,20,30,45,60,90,120,150,180,240,300$, and $360 \mathrm{~min}$ after isotope injection. An additional $3 \mathrm{ml}$ of blood was collected immediately before and at $30,60,90,120,240$, and $360 \mathrm{~min}$ after isotope injection. Breath samples $(50 \mathrm{ml})$ were collected 30,15 , and $2 \mathrm{~min}$ before and at $5,10,15,20,30,40,50,60,75,90,120,150,180,240,300$, and $360 \mathrm{~min}$ after isotope injection. Subjects received $\mathrm{L}-\left[{ }^{13} \mathrm{C}_{1}\right] l y$ sine/ $\mathrm{HCl}(5$ $\mathrm{mg} / \mathrm{kg}$ dissolved in $3 \mathrm{ml}$ of water) administered i.v. along with L$\left[{ }^{15} \mathrm{~N}_{2}\right]$ lysine/ $\mathrm{HCl}(5 \mathrm{mg} / \mathrm{kg}$ dissolved in $200 \mathrm{ml}$ of Gatoraid) administered orally.
Analytical procedures. The $\mathrm{CO}_{2}$ concentration of breath samples taken during the respiratory volume measurements was analyzed by gas-solid chromatography on a Carle 111 instrument (Carle Instruments Inc., Anaheim, CA) at a temperature of $350^{\circ} \mathrm{C}$, a helium gas flow of $90 \mathrm{ml} / \mathrm{min}$, and a concentric "CTR" column consisting of an outer $183 \times 6-\mathrm{mm}$ column containing molecular sieve and an inner $183 \times 3 \mathrm{~mm}$ column containing a Poropak mixture (no. 8700, Alltech Associates, Deerfield, IL). The chromatographic separation of $\mathrm{CO}_{2}, \mathrm{O}_{2}$, and $\mathrm{N}_{2}$ required 2 min. The composition of dry breath samples was calculated using a Hewlett-Packard 3390 integrating recorder (Hewlett-Packard Co., Palo Alto, CA). $\mathrm{CO}_{2}$ output was calculated from $\mathrm{CO}_{2}$ concentration and respiratory volume as previously described $(13) .{ }^{13} \mathrm{C} /{ }^{12} \mathrm{C}$ abundance of $\mathrm{CO}_{2}$ was measured by automated gas isotope ratio-mass spectrometry (14). ${ }^{13} \mathrm{C}$ abundance was calculated as delta per mil vs. the limestone standard, Pee Dee belemnite, and was converted to units of atom \% excess $\times 1,000$ (mAPE).

Plasma levels of endogenous lysine, $\left.\left[{ }^{15} \mathrm{~N}_{2}\right]\right]$ lysine, and $\left[{ }^{13} \mathrm{C}_{1}\right]$ lysine were determined by gas chromatography-mass spectrometry isotope ratiometry as described by Irving et al. (10). Lysine was isolated from plasma (500 $\mu l)$ on a cation-exchange resin from which it was eluted with $1 \mathrm{ml}$ of $3 \mathrm{~N}$ $\mathrm{NH}_{4} \mathrm{Cl}$ followed by $1 \mathrm{ml}$ of water. After evaporation of the eluate to dryness, lysine was converted to its dimethylaminomethylene methyl ester derivative by heating to $100^{\circ} \mathrm{C}$ for $10 \mathrm{~min}$ in $10 \mu \mathrm{l}, \mathrm{N}$-dimethylformamide dimethylacetal and $10 \mu \mathrm{l}$ of acetonitrile. Derivatized lysine was separated on a 122-cm gas chromatographic column packed with 3\% OV-17 on WHP 80/100 mesh (Alltech Associates, Deerfield, IL) and operated isothermally at $240^{\circ} \mathrm{C}$. Under these conditions, the lysine fraction eluted at $75 \mathrm{~s}$. Mass spectrometry was carried out on the mass to charge ratio $(\mathrm{m} / \mathrm{z}) 271,272$, and 273 ion signals in the chemical ionization mode using $\mathrm{NH}_{3}$ as the reagent gas. Ion intensity ratios were computed on-line using software written by W. M. Wong of our laboratory. Mole ratios of labeled lysine to endogenous lysine were calculated from the observed $\mathrm{m} / \mathrm{z} 271+272+273$ ion intensities of background plasma samples, from samples of labeled lysine, and from each plasma sample using the method described by Hachey et al. (15). The plasma level of endogenous lysine was obtained by the addition of $\left[{ }^{2} \mathrm{H}_{8}\right]$ lysine as an internal standard to plasma aliquots and measurement of the mole ratio of endogenous to $\left[{ }^{2} \mathrm{H}_{8}\right]$ lysine. Plasma levels of tracer lysines were calculated from the mole ratios and the level of endogenous lysine. All gas chromatographic mass spectrometric analyses were carried out in triplicate and the standard deviations for the analyses were propagated into subsequent calculations.

Computations. Data analysis and modeling were performed on the system previously described using SPEAKEZ (Argonne National Laboratory, Argonne, IL), a version of SAAM-27 (Simulation Analysis and Modeling, Version 27, National Institutes of Health, Bethesda, MD), modified to run interactively in CMS/Conversational Monitor System (IBM, Armonk, NY), and Tellagraf graphics software (Integrated Software Systems Corp., San Diego, CA) (16).

Model development. For the purpose of multicompartmental analysis, the following assumptions were made: $(a)$ The absorption, transport, and metabolism of lysine are linearized by the tracer experiment and can be regarded as first-order processes in the range of physiologic con-

Table II. Dietary Intakes before and during the Lysine Kinetic Measurements

\begin{tabular}{lllllrll}
\hline Subject & Energy & Energy & Protein & Protein & Lysine & Fat & Carbohydrate \\
\hline & $k c a l / d a y$ & $k c a l / k g$ & $g / d$ & $g / k g / d$ & $m g / k g / d$ & $g / d$ & $g / d$ \\
C1 & $1,400 / 1,600^{*}$ & $24 / 27$ & $66 / 56$ & $1.13 / 0.075$ & $88 / 75$ & $63 / 48$ & $150 / 228$ \\
C2 & $1,800 / 1,800$ & $35 / 35$ & $44 / 62$ & $0.85 / 1.20$ & $66 / 93$ & $49 / 58$ & $280 / 257$ \\
C3 & $1,500 / 1,500$ & $29 / 29$ & $82 / 62$ & $1.57 / 1.18$ & $122 / 92$ & $33 / 48$ & $231 / 205$ \\
C4 & $1,700 / 1,800$ & $26 / 27$ & $80 / 78$ & $1.21 / 1.18$ & $95 / 92$ & $71 / 55$ & $188 / 255$ \\
C5 & $1,400 / 1,300$ & $21 / 19$ & $56 / 51$ & $0.84 / 0.76$ & $65 / 59$ & $36 / 41$ & $220 / 188$ \\
Mean \pm SD & $1,560 \pm 180 / 1,600 \pm 210$ & $26 \pm 3 / 27 \pm 4$ & $66 \pm 16 / 62 \pm 10$ & $1.11 \pm 0.27 / 1.04 \pm 0.17$ & $86 \pm 21 / 81 \pm 13$ & $50 \pm 16 / 50 \pm 6.7$ & $214 \pm 49 / 227 \pm 30$ \\
\hline
\end{tabular}

* Dietary intake before the lysine protocol/dietary intake during the lysine protocol (Sustacal diet). 
centrations encountered in normal subjects. $(b)$ In subjects who were equilibrated on a liquid formula diet for at least $3 \mathrm{~d}$ and who were receiving four feedings per day, the period of 4-10 $\mathrm{h}$ after a liquid formula meal represented a period of "quasi-stationary" metabolism during which all kinetic parameters were time invariant, even though the system was nonstationary over a longer period of time. $(c)$ Labeled $\mathrm{CO}_{2}$ generated inside a cell will enter the capillary bed rapidly and be converted to labeled bicarbonate, which will have the same distribution throughout body pools and metabolites as intravenously administered bicarbonate. (d) Labeled lysine administered orally as an isotonic solution will be absorbed in a first-order kinetic process and will pass through the splanchnic bed before appearing in plasma. (e) The decarboxylation of lysine occurs exclusively in the splanchnic tissues and not in muscle or extracellular spaces. $(f)$ Protein synthesis does not occur in extracellular spaces. $(g)\left[{ }^{13} \mathrm{C}_{1}\right]$ - and $\left[{ }^{15} \mathrm{~N}_{2}\right]$ lysine are eliminated from the circulation at the same rate.

The uptake of amino acids into extracellular spaces and their incorporation into protein are nonlinear processes when measured over a wide range of intra- and extracellular concentrations (17). The hepatic extraction of enterally administered amino acids is also nonlinear and increases with increasing protein intake (18). However, all tracer methods currently used to estimate protein synthesis in the whole animal are based on the linearization (19) by the tracer experiment of a nonlinear system (assumption $a$ ), i.e., a doubling of the incorporation of endogenous amino acid into protein will be accompanied by a doubling in the amount of tracer incorporated into protein, provided the tracer dose is small enough. Analysis of oral tracer data (assumption $d$ ) presumes the absence of portal-systemic shunting and saturation of intestinal absorption by the tracer lysine dose, which appears to be reasonable for the normal subjects who were studied.

Determination of the minimum number of pools in the system. Two-, three-, and four-multiexponential equations were fitted to the levels of $\left[{ }^{13} \mathrm{C}_{1}\right]$ lysine observed after i.v. bolus injection in each of the five subjects studied. The two-exponential equation could not account for the shape of the disappearance curves, whereas the use of the four-exponential equation resulted in large uncertainties in the estimated parameters. When the three-exponential equation was fitted to the disappearance curves of $\left[{ }^{13} \mathrm{C}_{1}\right]$ lysine, coefficients of variation of less than 0.05 and standard deviations of $<15 \%$ of the estimated parameters were obtained for each of the five subjects. These figures indicated that the compartmental model order was three, and that the lysine system contained at least three resolvable compartments. Had the number of resolvable compartments been only two, it would not have been possible to partition lysine metabolism into pools with fast and slow turnover. Estimated parameters were obtained from Eq. 1,

$C_{t}^{\mathrm{iv}}=A_{1} \mathrm{e}^{-k_{1} t}+A_{2} \mathrm{e}^{-k_{2} t}+A_{3} \mathrm{e}^{-k_{3} t}$,

where $C_{\mathrm{t}}$ is the plasma level of labeled lysine at time $t, A_{i}$ is the preexponential term, and $k_{i}$ is the decay term.

Multiexponential analysis of $\left[{ }^{15} \mathrm{~N}_{2}\right]$ lysine data. The plasma levels of orally administered $\left[{ }^{15} \mathrm{~N}_{2}\right]$ lysine were fitted to two-, three-, and fourexponential equations. Best fits, judged by coefficients of variation and the percent standard deviations of the estimated parameters, were obtained from the use of the three-exponential equation given by Eq. 2,

$C_{t}^{0}=A_{4} \mathrm{e}^{-k 4 t}+A_{5} \mathrm{e}^{-k s t}+A_{6} \mathrm{e}^{-k_{6} t}$.

Determination of noncompartmental kinetic parameters. A number of descriptive parameters, such as the systemic availability of orally administered lysine (SA), initial space $\left(V_{c}\right)$, total half-life $\left(t_{1}\right)$, and time $\left(t_{r}\right)$ required for orally administered lysine to rise to maximum plasma levels starting at the time of the first detectable level of labeled lysine in plasma $\left(t_{0}\right)$, can be derived for i.v. administered $\left[{ }^{13} \mathrm{C}_{1}\right]$ lysine (iv) and orally administered [ $\left.{ }^{15} \mathrm{~N}_{1}\right]$ lysine (o) using Eqs. 3-12 (11): where AUC is the area under the respective plasma disappearance curve, $C_{0}$ is the extrapolated plasma level of labeled lysine at zero time, $t_{\max }$ is the time that maximal plasma levels of labeled lysine are achieved, and $t_{0}$ and $t_{\max }$ are estimated by visual inspection of the curves. In Eq. 4, the area under the curve is corrected by the term $C_{\mathrm{t}}^{0} \mathrm{~d} t$, which is the negative area under the curve from time 0 to $t_{0}$, that arises from the fit of a multiexponential equation to the delayed appearance of an orally administered tracer.

$$
\begin{aligned}
& \mathrm{AUC}^{\mathrm{iv}}=\left(A_{1} / k_{1}\right)+\left(A_{2} / k_{2}\right)+\left(A_{3} / k_{3}\right) \\
& \mathrm{AUC}=\left(A_{4} / k_{4}\right)+\left(A_{5} / k_{5}\right)+\left(A_{6} / k_{6}\right)-C_{t}^{0} \mathrm{~d} t \\
& \mathrm{SA}=\mathrm{AUC}^{\circ} / \mathrm{AUC}^{\mathrm{iv}} \\
& C_{0}^{\mathrm{iv}}=A_{1}+A_{2}+A_{3} \\
& V_{\mathrm{c}}^{\mathrm{iv}}=\operatorname{dose}^{\mathrm{iv}} / C_{0}^{\mathrm{iv}} \\
& V_{\mathrm{T}}^{\mathrm{iv}}=\operatorname{dose}^{\mathrm{iv}} /\left(k_{3} \mathrm{AUC}^{\mathrm{iv}}\right) \\
& V_{\mathrm{T}}^{\mathrm{o}}=\operatorname{dose}^{\mathrm{o}} /\left(k_{6} \mathrm{AUC}^{\mathrm{o}}\right) \\
& t_{\frac{1}{\mathrm{iv}}}^{\mathrm{iv}}=0.693 / k_{3} \\
& t_{1}^{\mathrm{o}}=0.693 / k_{3} \\
& t_{\mathrm{r}}=t_{\max }-t_{0}
\end{aligned}
$$

Development of the multicompartmental model. The objective of the model building process was to derive a model of lysine kinetics in humans from the plasma and breath kinetic data that embodied the essential features of the multicompartmental model of lysine kinetics derived from animal studies. The special feature of the model was independent estimates of liver and muscle protein synthesis. Aub and Waterlow (20) assembled a multicompartmental model for lysine kinetics in the rat from literature values of protein synthetic rates and amino acid transport. Their model consisted of a central plasma compartment connected to a liver extracellular fluid compartment and to a muscle extracellular fluid compartment. The extracellular compartments were connected, respectively, to the liver and muscle intracellular free amino acid compartments. A reasonable approximation of their model is a three-compartment model in which plasma and extracellular compartments are combined in a single central compartment. Thus the core of all multicompartmental models of lysine kinetics consists of a central compartment that contains a plasma pool connected to fast- and to slow-exchanging peripheral pools.

The first step in the model-building process was to fit a mammillary three-compartment model (model 1, Fig. 1) to the plasma levels of i.v. administered $\left[{ }^{13} \mathrm{C}_{1}\right]$ lysine. The central pool is labeled $c$, the peripheral pool whose free lysine rapidly exchanges with the central compartment is labeled $f$ and the peripheral pool which exchanges more slowly is labeled

Model 1

Model 2
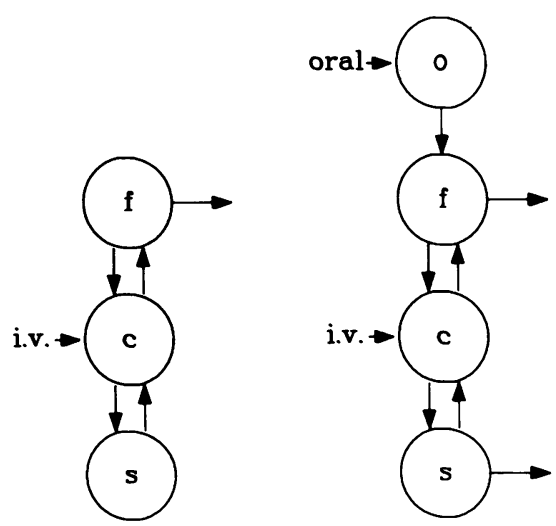

Figure 1. Model 1: three-compartment mammillary model describing the plasma disappearance data of i.v. administered L- $\left[{ }^{13} \mathrm{C}_{1}\right]$ lysine. Model 2: four-compartment linear model describing the plasma disappearance data of both i.v. administered $L-\left[{ }^{13} \mathrm{C}_{1}\right]$ lysine and orally administered L- $\left[{ }^{15} \mathrm{~N}_{2}\right]$ lysine. Central, fast-exchanging peripheral, and slowly exchanging peripheral compartments are denoted by $c, f$, and $s$, respectively. 
$s$. The irreversible loss of tracer was allowed to occur from compartment $f$. The three-compartment model could be fitted to the plasma data of all five subjects.

The next step in the model building process was to partition irreversible loss of tracer between the $f$ and $s$ peripheral compartments by fitting the model to plasma levels of i.v. administered $\left[{ }^{13} \mathrm{C}_{1}\right]$ lysine and orally-administered $\left[{ }^{15} \mathrm{~N}_{2}\right]$ lysine (model 2 , Fig. 1). Orally administered lysine was admitted to a single compartment, labeled $o$, which emptied into compartment $f$ (see assumption $d$ ) in which lysine was either irreversibly lost via metabolism (oxidation and protein synthesis) or exported to the central compartment. The ratio of metabolism to export was fixed by the reduction in the circulating levels of orally administered compared with i.v. administered lysine. Because both lysine tracers shared the same set of systemic fractional rate constants (see assumption $f$ ), the rate constant for the irreversible loss of i.v. administered lysine from compartment $s$ was estimated from the observed plasma elimination and the elimination rate constant for compartment $f$. The four-compartment model accounted for both the gastrointestinal absorption and systemic metabolism of lysine.

Model 2 can be shown to fulfill the two requirements described by Cobelli et al. $(21,22)$ that are necessary for a multicompartmental model to be system identifiable. First, the system is output-input connectable, because the sites of oral and i.v. administration of tracers are connected to the site of plasma sampling by defined pathways. Second, the number of unknown model parameters, seven rate constants, and one common volume of dilution for the orally and i.v. administered tracers does not exceed the maximum number of estimable parameters, which is eight for model 2. This number was determined in the following manner using the method described by Cobelli et al. $(21,22)$. The number of compartments $(n)$ in model 2 is four. The tracer experiment was designed so that there were two input-output subsystems, i.e., i.v. administration into the central pool $(c)$ with i.v. sampling from the central pool $(c)$ denoted by $c c$, and oral administration into the oral pool $(o)$ with i.v. sampling from the central pool (c) denoted by $o c$. For the $c c$ subsystem, the term $W_{c c}$, which is the number of compartments in the subsystem minus the length of the shortest path minus 1 , is $3-0-1$. For the $o c$ subsystem, the term $W_{o c}$, which is the number of compartments minus the length of the shortest path, is $4-2$. The maximum number of estimable parameters is given $(21,22)$ by $n+W_{c c}+W_{o c}$, which is $4+2$ +2 . The small fractional standard deviations obtained for eight model parameters when fitted to plasma data indicated that model 2 was also parameter identifiable. Model 2 is not unique in the respect that variants of the model could be fitted to the plasma data. However, model 2 was the only configuration that was consistent with the goals of the model development process and partitioned lysine elimination between the two peripheral pools.

The next step in the model building process was the partitioning of lysine metabolism into oxidation and protein synthesis. The incorporation of breath ${ }^{13} \mathrm{CO}_{2}$ data into the calculations required the use of a bicarbonate subsystem that accounted for the losses and delays in ${ }^{13} \mathrm{CO}_{2}$ excretion associated with the passage of labeled carbon through metabolic carbon and bicarbonate pools.

Determination of the bicarbonate subsystem. Bicarbonate kinetics are affected by diet, metabolic status, and level of activity. We previously had determined bicarbonate subsystems for young adult volunteers in either the overnight-fasted state (13) or the continuously fed state (23). These systems, however, were not appropriate for the formula-fed female volunteers for the 4-10-h postprandial period required in this study. Therefore, a new set of bicarbonate kinetic parameters was obtained for these subjects.

The three-compartment model previously described (13) for adult male volunteers, who were fasted overnight and were in a resting state, was fitted to the levels of ${ }^{13} \mathrm{CO}_{2}$ in breath obtained during the bicarbonate kinetic measurements. It was expected that the qualitative features of the bicarbonate $/ \mathrm{CO}_{2}$ system would be the same in male and female subjects, but that quantitative differences would be found in the rates of elimination and transfer of bicarbonate between compartments, consistent with a postprandial period of $4 \mathrm{~h}$ in the female volunteers. As seen in Fig. 2, the bicarbonate model consisted of a central compartment, $c$,

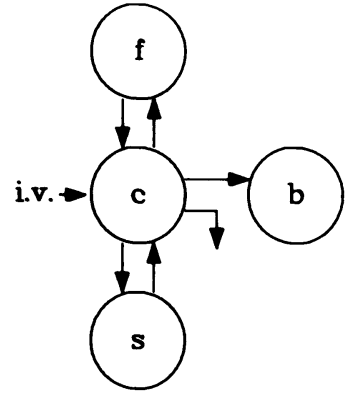

Figure 2. Three-compartment mammillary model used to describe the output of ${ }^{13} \mathrm{CO}_{2}$ in breath following the i.v. bolus administration of $\mathrm{NaH}^{13} \mathrm{CO}_{3}$. Central, fast-exchanging peripheral, and slowly exchanging peripheral are denoted by $c, f$, and $s$ and breath is denoted by $b$.

that included the plasma into which the labeled bicarbonate was introduced. Labeled bicarbonate in the central compartment underwent a fast exchange with one peripheral compartment, $f$, and a slower exchange with a second peripheral compartment, $s$. Labeled bicarbonate could be lost from the central compartment either by elimination in the form of breath $\mathrm{CO}_{2}$ or by exchange of labeled $\mathrm{CO}_{2}$ with nonlabeled carboxyl groups of metabolic intermediates, by exchange with a large pool of bicarbonate undergoing slow turnover as in bone, or by renal excretion. The latter three processes have been summed together and are represented by the irreversible loss of labeled bicarbonate from the central compartment. These transfer processes are described by six fractional rate constants. Estimates of pool sizes were obtained by steady-state solution using each subject's measured $\mathrm{CO}_{2}$ output rate. Convergence, as defined by Berman and Weiss (24), was obtained in each case.

Partitioning of lysine metabolism. To obtain the rate constants for the incorporation of tracer lysine into protein, the fraction of the irreversible loss of lysine that resulted from oxidation had to be determined. Based on the assumption that all lysine oxidation occurred in compartment $f$ (see assumption $e$ ), an additional pathway was added that led from this compartment to compartment $b f$ of the bicarbonate subsystem (model 3, Fig. 3). (To avoid confusion in the nomenclature of the lysine and bicarbonate $c, f$, and $s$ compartments, the prefixes $l$ and $b$ have been added to the names of the lysine and bicarbonate compartments, respectively, so that $l c$ and $b c$ refer to the central lysine and bicarbonate pools, respectively.) The bicarbonate subsystem initially was defined by the set of fractional rate constants determined the previous day in each subject. This model was fitted to the plasma tracer lysine levels and breath ${ }^{13} \mathrm{CO}_{2}$ levels. The configuration of $\mathrm{CO}_{2}$ elimination pathways, however, failed to account for the very rapid rise in breath ${ }^{13} \mathrm{CO}_{2}$ levels observed immediately after the i.v. administration of $\left[{ }^{13} \mathrm{C}_{1}\right]$ lysine. To account for this rise, an alternate model was constructed in which the additional pathway was redirected to the central pool of the bicarbonate subsystem, $b c$, (model 4, Fig. 3). This model also failed to account for the pattern of labeled $\mathrm{CO}_{2}$ output. Either the systemic model of lysine metabolism or the pathway for $\mathrm{CO}_{2}$ elimination had to be altered to explain the pattern. The rapid early output of ${ }^{13} \mathrm{CO}_{2}$ could be accounted for in all five subjects by allowing $\mathrm{CO}_{2}$ generated from the lf compartment to enter a "metabolic carbon pool," $m c$, a portion of which was eliminated directly in the breath compartment and part of which was emptied into the BS compartment (model 5, Fig. 4). Even though the physiologic basis of such a pathway of $\mathrm{CO}_{2}$ elimination was not known, this model proved to be the one with the smallest set of fractional rate constants that could be fit to both plasma and breath data and be consistent with the goals of the model building process.

Determination of pool sizes, transfer rates, and flux. The fractional rate constants derived thus far describe the kinetics of tracer lysines. In the final phase of multicompartmental analysis, information obtained from the kinetics of tracer lysine was used to obtain three types of parameters that describe the kinetics of unlabeled free lysine. These were (a) pool sizes, the amount of free lysine in each of the three compartments, (b) transfer rates in units of micromoles per kilogram/minute obtained by multiplying the fractional rate constant of tracer lysine by the appropriate lysine pool size, and $(c)$ whole-body lysine flux. Under steadystate conditions, flux is equal both to the sum of all the inputs, i.e., protein breakdown in the $s$ and $f$ compartments, and to the sum of all 
Model 3

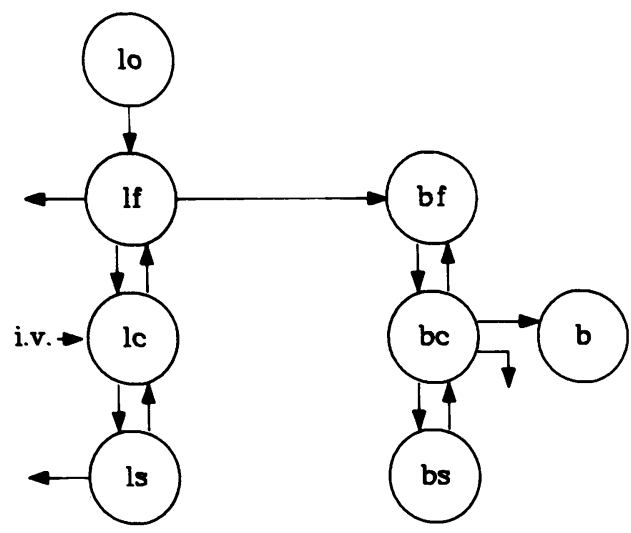

Model 4

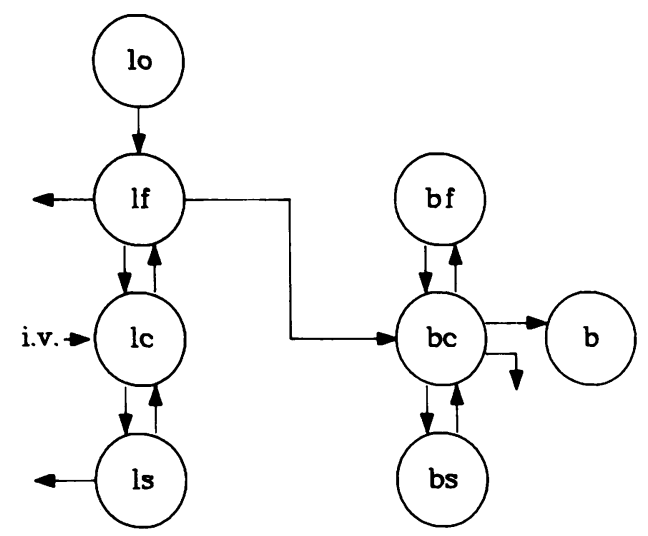

Figure 3. Combined lysine and bicarbonate models that could not be fitted to breath ${ }^{13} \mathrm{CO}_{2}$ levels obtained after the i.v. administration of $\mathrm{L}$ $\left[{ }^{13} \mathrm{C}_{1}\right]$ lysine. Lysine central, fast-exchanging peripheral, slowly exchanging peripheral, and oral compartments are denoted by $l c, l f, l s$, and $l o$, respectively. Bicarbonate central, fast-exchanging peripheral, and slowly exchanging peripheral are denoted by $b c, b f$, and $b s$, and breath is denoted by $b$.

\section{Model 5}

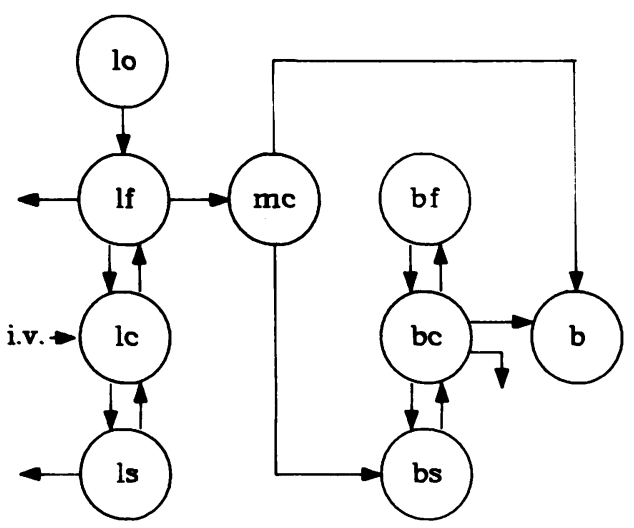

Figure 4. Combined lysine and bicarbonate models that were fitted simultaneously to breath ${ }^{13} \mathrm{CO}_{2}$ levels obtained after the i.v. administration of $\mathrm{L}-\left[{ }^{13} \mathrm{C}_{1}\right]$ lysine, breath ${ }^{13} \mathrm{CO}_{2}$ levels obtained after the i.v. administration of $\mathrm{NaH}^{13} \mathrm{CO}_{3}$, and the plasma levels of tracer lysines. The lysine component of the "metabolic carbon pool" is denoted by $m c$. Other abbreviations are given in Fig. 3. the outputs, i.e., protein synthesis in the $s$ and $f$ compartments and oxidation. Estimates of flux obtained in this manner from multicompartmental analysis parameters are equivalent to the value for flux calculated from plateau enrichments obtained during the constant infusion of labeled lysine. The calculation of pool sizes, transfer rates, and flux required two additional types of information. These were $(a)$ the size of the central lysine pool obtained by multiplying the plasma lysine level by the volume of the central pool and $(b)$ the sites and relative rates of protein breakdown. Solutions were calculated for the boundary conditions in which protein breakdown occurred exclusively either in the fast- or the slow-exchanging pool. Various intermediate solutions were also calculated. Lysine pool sizes and kinetic parameters reported here were calculated for the condition of balanced protein synthesis and breakdown in the slow-exchange compartment. This condition is characterized by no net lysine uptake or release across muscle. The choice of this condition seemed reasonable because measurements of arteriovenous differences across muscle of plasma free amino acid levels have shown lysine uptake by muscle has fallen to near zero values by 3-4 $\mathrm{h}$ after a protein meal $(7,8)$.

\section{Results}

Plasma levels of tracer lysines. The disappearance curve of i.v. administered $\mathrm{L}-\left[{ }^{13} \mathrm{C}_{1}\right]$ lysine, shown in Fig. 5 for five subjects, could be described by a three-exponential decay function (Eq. 1) whose constants are given in Table III. Plasma levels of tracer lysines ranged from 200 to $2 \mathrm{nmol} / \mathrm{ml}$ over the course of 360 min, and could be measured with an precision of $<1 \mathrm{nmol} / \mathrm{ml}$ (SD). Lysine kinetics also could be described in a noncompartmental manner using kinetic parameters (Table IV) derived from the multiexponential decay constants (Table III). The initial volume of distribution had a mean value of $195 \mathrm{ml} / \mathrm{kg}$, while the total volume of distribution was $1,523 \mathrm{ml} / \mathrm{kg}$, indicating that lysine had been taken up into tissues whose intracellular lysine levels exceeded those in plasma. The terminal half-life of i.v. administered tracer lysine was $17.7 \mathrm{~min}$.

The disappearance curve of orally administered L$\left[{ }^{15} \mathrm{~N}_{2}\right]$ lysine, shown in Fig. 5 for five subjects, also could be described by a three-exponential decay function (Eq. 2), whose constants are given in Table V. Plasma levels ranged from 60 to $1.5 \mathrm{nmol} / \mathrm{ml}$ over the course of $360 \mathrm{~min}$, and could be measured with precision of $<1 \mathrm{nmol} / \mathrm{ml}$ (SD). Noncompartmental kinetic parameters derived from the multiexponential decay constants are given in Table VI. The negative zero-time tracer lysine levels indicated the presence of a delay in the appearance of orally administered tracer lysine that ranged from 7.3 to 14.1 min. The time required to reach peak plasma levels was an additional 13.3-26.8 min. The total systemic availability of orally administered lysine, derived from the areas under the plasma curves of i.v. and orally administered tracer lysines, had a mean value of 0.79 . The total volume of distribution $(1,746 \mathrm{ml} / \mathrm{kg})$ and terminal half-life $(19.2 \mathrm{~min})$ were equivalent to the values of i.v. administered tracer lysine.

Breath ${ }^{13} \mathrm{CO}_{2}$ levels. After the i.v. administration of $\mathrm{L}$ $\left[{ }^{13} \mathrm{C}_{1}\right]$ lysine, breath levels of excess ${ }^{13} \mathrm{CO}_{2}$ rose to maximum values at $18 \pm 8.3 \mathrm{~min}$ (mean + SD for five subjects) and subsequently decayed with a terminal rate constant of $29.1 \pm 4.5 \% / \mathrm{h}$ The maximum rate of ${ }^{13} \mathrm{CO}_{2}$ excretion was $7.0 \pm 2.2 \%$ dose/h and decreased to $2.9 \pm 0.6 \%$ dose/h by $2 \mathrm{~h}$. The total percent dose recovery of administered ${ }^{13} \mathrm{C}$ in breath $\mathrm{CO}_{2}$ was $9.0 \pm 2.3 \%$ over $2 \mathrm{~h}$, while the total recovery extrapolated to infinite time was $15.4 \pm 3.3 \%$. The lysine breath test curves were distinguished by the relatively early times at which peak outputs were achieved compared with those of other substrates. 

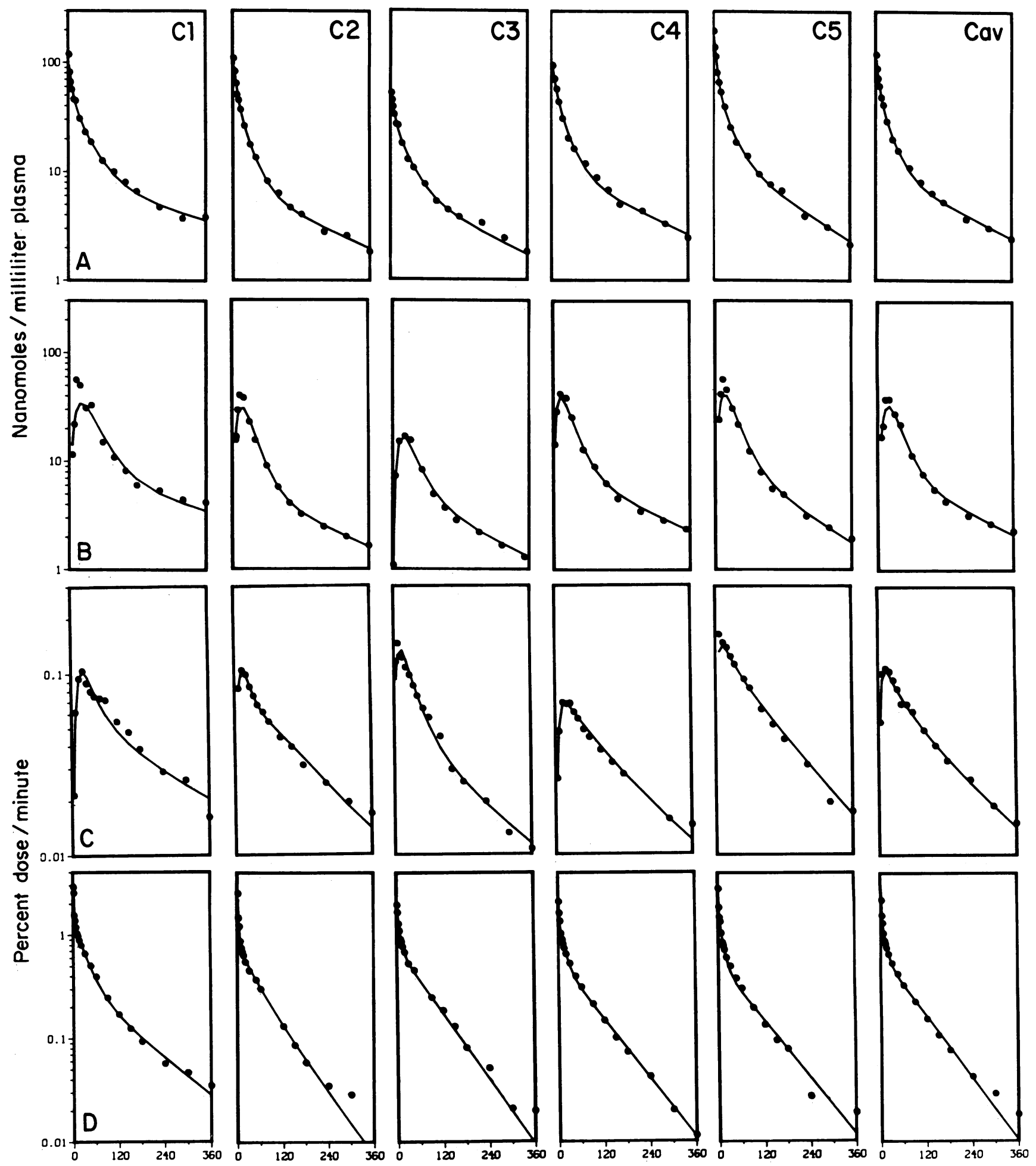

Time (minutes)

Figure 5. Observed (๑) and calculated $\left(\longrightarrow\right.$ values of $(A)$ plasma $\left[{ }^{13} \mathrm{C}_{1}\right] l y s i n e,(B)\left[{ }^{15} \mathrm{~N}_{1}\right]$ lysine, $(C)$ breath ${ }^{13} \mathrm{CO}_{2}$ after $\left[{ }^{13} \mathrm{C}_{1}\right] l y s i n e$, and $(D)$ breath ${ }^{13} \mathrm{CO}_{2}$ after $\mathrm{NaH}^{13} \mathrm{CO}_{3}$ for subjects, $\mathrm{Cl}-\mathrm{C} 5$, and the set of averaged subjects' curves (Cav) Calculated values were obtained using the complete set of fractional rate constants given in Table VII and model 5 shown in Fig. 4.

Bicarbonate kinetic parameters. The bicarbonate multicompartment model previously applied to adult subjects, who were in the resting state and who had fasted overnight, could be fitted without difficulty to the levels of excess ${ }^{13} \mathrm{CO}_{2}$ in breath after the administration of $\mathrm{NaH}^{13} \mathrm{CO}_{3}$ to subjects in this study. Female subjects in a resting state over the period of $4-10 \mathrm{~h}$ after a formula meal were found to have central, fast-exchanging peripheral, and slow-exchanging peripheral pools containing $2,564 \pm 1,410$, $5,280 \pm 2,699$, and $6,875 \pm 1,714 \mu \mathrm{mol} / \mathrm{kg}$, respectively, of bicarbonate $/ \mathrm{CO}_{2} /$ metabolic carbon. The total flux was $187 \pm 16 \mu \mathrm{mol} /$ 
Table III. Multiexponential Parameters

for Plasma Levels of I.V. Administered $L_{-}\left[{ }^{13} C_{I}\right]$ Lysine

\begin{tabular}{lrrrlll} 
Subject & \multicolumn{1}{c}{$A_{1}$} & \multicolumn{1}{c}{$A_{2}$} & \multicolumn{1}{c}{$A_{3}$} & \multicolumn{1}{l}{$k_{1}$} & \multicolumn{1}{l}{$k_{2}$} & \multicolumn{1}{l}{$k_{3}$} \\
\hline & & \multicolumn{1}{c}{$\mathrm{nmol} / \mathrm{ml}$} & & $\mathrm{min}^{-1}$ & $\mathrm{~min}^{-1}$ & $\mathrm{~min}^{-1}$ \\
$\mathrm{C} 1$ & 162 & 50.5 & 10.8 & 0.342 & 0.0267 & 0.00323 \\
$\mathrm{C} 2$ & 101 & 47.2 & 7.6 & 0.181 & 0.0309 & 0.00391 \\
$\mathrm{C} 3$ & 30 & 31.1 & 7.7 & 0.224 & 0.0336 & 0.00395 \\
C4 & 82 & 26.7 & 8.4 & 0.079 & 0.0187 & 0.00336 \\
C5 & 266 & 86.6 & 19.1 & 0.323 & 0.0446 & 0.00619 \\
Mean & 128 & 48.2 & 10.7 & 0.229 & 0.0309 & 0.00412 \\
SD & 90 & 23.6 & 4.8 & 0.107 & 0.0095 & 0.00119
\end{tabular}

$\mathrm{kg} / \mathrm{min}$ of which $134 \pm 9 \mu \mathrm{mol} / \mathrm{kg} / \mathrm{min}$ was output to respiratory $\mathrm{CO}_{2}$. The total percent dose recovery of administered ${ }^{13} \mathrm{C}$ extrapolated to infinite time was $72 \pm 6 \%$. This set of bicarbonate kinetic parameters more closely resembled those of adult subjects in the continuously fed state than those of overnight fasted subjects.

Lysine multicompartmental model. The lysine multicompartmental model that was developed from the steps outlined in Methods (see Fig. 4) was fitted to the curves of each of the five subjects (C1-C5) as well as to a set of curves (Cav) obtained by averaging the plasma and breath data of the five subjects. The fit of the calculated plasma and breath values to plasma $\left[{ }^{13} \mathrm{C}_{1}\right]$ lysine and $\left[{ }^{15} \mathrm{~N}_{2}\right]$ lysine and breath excess ${ }^{13} \mathrm{CO}_{2}$, as well as to breath ${ }^{13} \mathrm{CO}_{2}$ obtained from labeled bicarbonate is shown in Fig. 5. The model could simultaneously reproduce the shape of the four curves for all of the subjects, especially the rapid output of ${ }^{13} \mathrm{CO}_{2}$ after the i.v. administration of $\left[{ }^{13} \mathrm{C}_{1}\right]$ lysine. However, in subjects $\mathrm{C} 1, \mathrm{C} 2$, and $\mathrm{C} 5$, the model slightly underestimated the peak plasma values of orally administered $\left[{ }^{15} \mathrm{~N}_{1}\right]$ lysine. The fractional rate constants and their standard deviations are given in Table VII for the five subjects and the averaged subject curves. Pool sizes, transfer rates, and inputs of endogenous lysine are given in Table VIII for the steady-state solution based on the case of free lysine balance in the slow-exchanging peripheral pool.

The lysine multicompartmental model possessed the following features: using the parameters derived from the averaged

Table IV. Noncompartmental Kinetic Parameters Derived from Plasma $L-\left[{ }^{13} C_{I}\right]$ Lysine Levels

\begin{tabular}{|c|c|c|c|c|c|}
\hline Subject & AUC $^{\mathrm{iv}}$ & $C_{0}^{\mathrm{iv}}$ & $t_{h}^{\mathrm{iv}}$ & $V_{\mathrm{c}}^{\mathrm{iv}}$ & $V_{\mathbf{T}}^{\text {iv }}$ \\
\hline & $\mathrm{nmol} \cdot \mathrm{min} / \mathrm{ml}$ & $n \mathrm{~mol} / \mathrm{ml}$ & $\min$ & $\mathrm{ml} / \mathrm{kg}$ & $\mathrm{ml} / \mathrm{kg}$ \\
\hline $\mathrm{Cl}$ & 5,714 & 223 & 214.5 & 100.3 & 1,213 \\
\hline $\mathrm{C} 2$ & 4,042 & 155 & 177.2 & 175.8 & 1,733 \\
\hline $\mathrm{C} 3$ & 3,030 & 69 & 175.4 & 395.1 & 2,281 \\
\hline $\mathrm{C} 4$ & 4,966 & 117 & 206.2 & 232.5 & 1,635 \\
\hline $\mathrm{C} 5$ & 5,853 & 372 & 111.9 & 73.3 & 753 \\
\hline Mean & 4,721 & 187 & 177.0 & 195.4 & 1,523 \\
\hline SD & 1,188 & 117 & 40.3 & 128.0 & 574 \\
\hline
\end{tabular}

Parameter definitions are: AUC, area under curve (Eq. 3); $C_{0}^{\text {iv }}$, plasma level at time 0 (Eq. 6); $t_{1 / 2}^{\text {iv }}$, terminal half-life (Eq. 10 ); $V_{c}^{\text {iv }}$, initial volume of distribution (Eq. 7); $V_{\mathrm{T}}^{\mathrm{iv}}$, final volume of distribution (Eq. 8).
Table V. Multiexponential Parameters

for Plasma Levels of Orally Administered $L-\left[{ }^{15} N_{2}\right]$ Lysine

\begin{tabular}{lrrrlll}
\hline Subject & \multicolumn{1}{l}{$A_{1}$} & \multicolumn{1}{c}{$A_{2}$} & \multicolumn{1}{c}{$A_{3}$} & \multicolumn{1}{l}{$k_{1}$} & \multicolumn{1}{l}{$k_{2}$} & \multicolumn{1}{l}{$k_{3}$} \\
\hline & & \multicolumn{1}{l}{$\mathrm{nmol} / \mathrm{ml}$} & & $\mathrm{min}^{-1}$ & $\mathrm{~min}^{-1}$ & $\mathrm{~min}^{-1}$ \\
$\mathrm{Cl}$ & -426 & 362.0 & 10.59 & 0.056 & 0.0395 & 0.00273 \\
$\mathrm{C} 2$ & -263 & 84.5 & 5.78 & 0.155 & 0.0328 & 0.00355 \\
$\mathrm{C} 3$ & -346 & 298.8 & 5.03 & 0.045 & 0.0369 & 0.00377 \\
$\mathrm{C} 4$ & -309 & 146.4 & 7.55 & 0.087 & 0.0318 & 0.00327 \\
C5 & -282 & 101.3 & 9.43 & 0.156 & 0.0319 & 0.00450 \\
Mean & -325 & 198.6 & 7.67 & 0.099 & 0.0345 & 0.00356 \\
SD & 64 & 124.4 & 2.35 & 0.052 & 0.0034 & 0.00065
\end{tabular}

tracer curves (Cav), orally administered lysine initially entered compartment $o$ (Fig. 4). After a delay of $\sim 10 \mathrm{~min}\left(t_{0}\right)$, orally administered lysine was emptied, in a first-order kinetic process with a half-life of $8.49 \mathrm{~min}\left(t_{\frac{1}{2}}^{G}\right)$, into compartment $l f$ that contained $37.1 \mu \mathrm{mol} / \mathrm{kg}$ of endogenous lysine. Of the lysine that entered the fast-exchanging peripheral lysine compartment (lf), 9.6\% was oxidized $\left(R_{m c, l}\right)$ and $11.8 \%$ was removed by nonoxidative pathways $\left(R_{P r, l f}\right)$, primarily protein synthesis. Thus, $21.5 \%$ of orally administered tracer lysine was eliminated on its first passage through compartment $l f$. The remainder passed into the central compartment $(l c)$, which was the compartment into which i.v. administered lysine initially entered. No elimination occurred from the central compartment, which contained $38.5 \mu \mathrm{mol} / \mathrm{kg}$ of endogenous lysine and had a volume of dilution of $188 \mathrm{ml} /$ $\mathrm{kg}$. Of the tracer lysine in the central compartment, $63.9 \%$ returned to the fast-exchanging compartment (lf), while $36.1 \%$ passed into a slow-exchanging compartment $(l s)$. The slow-exchanging compartment $(l s)$ was the largest free lysine compartment and contained almost 10 times the amount of free lysine as either compartment lf or $l c$. No oxidation of lysine was assumed to occur in the slow-exchanging compartment $(l s) .40 \%$ of the free lysine leaving compartment $l s$ (either by incorporation into protein or transport back to the central compartment) was incorporated into protein.

A unique and unexpected feature of the model concerned the fate of $\mathrm{CO}_{2}$ generated by lysine oxidation in compartment lf.

Table VI. Noncompartmental Kinetic Parameters Derived from Plasma $L_{-}\left[{ }^{15} N_{2}\right]$ Lysine Levels

\begin{tabular}{|c|c|c|c|c|c|c|}
\hline Subject & $\mathrm{AUC}^{\circ}$ & SA & $t_{0}$ & $t_{\mathrm{r}}$ & $t_{y_{2}}{ }^{\circ}$ & $V_{T^{\circ}}$ \\
\hline & $\mathrm{nmol} \cdot \mathrm{min} / \mathrm{ml}$ & none & $\min$ & $\min$ & $\min$ & $\mathrm{ml} / \mathrm{kg}$ \\
\hline $\mathrm{Cl}$ & 5,642 & 0.987 & 7.4 & 23.1 & 253 & 1,756 \\
\hline $\mathrm{C} 2$ & 3,074 & 0.760 & 8.6 & 13.3 & 195 & 1,902 \\
\hline C3 & 2,059 & 0.679 & 14.1 & 26.8 & 183 & 2,372 \\
\hline $\mathrm{C} 4$ & 4,116 & 0.828 & 12.2 & 19.3 & 211 & 1,668 \\
\hline $\mathrm{C} 5$ & 3,964 & 0.677 & 7.3 & 13.6 & 154 & 1,032 \\
\hline Mean & 3,771 & 0.786 & 9.9 & 19.2 & 199 & 1,746 \\
\hline SD & 1,329 & 0.128 & 3.0 & 5.8 & 36 & 482 \\
\hline
\end{tabular}

Parameter definitions are: AUC ${ }^{\circ}$, area under curve (Eq. 4); SA, systemic availability (Eq. 5 ); $t_{0}$, time of appearance of tracer in plasma; $t_{\mathrm{r}}$, elapsed time from appearance to maximal level (Eq. 12); $t_{4_{2}}{ }^{\circ}$, terminal half-life (Eq. 11); $V_{\mathrm{T}}^{\circ}$, final volume of dilution (Eq. 9). 
Table VII. Fractional Rate Constants Describing the Kinetics of Tracer Lysine and Bicarbonate

\begin{tabular}{|c|c|c|c|c|c|c|c|}
\hline \multirow{2}{*}{$\begin{array}{l}\text { Fractional } \\
\text { rate constant }\end{array}$} & \multicolumn{7}{|l|}{ Subjects } \\
\hline & $\mathrm{Cl}$ & $\mathrm{C} 2$ & $\mathrm{C} 3$ & $\mathrm{C} 4$ & C5 & Cav & Mean \\
\hline \multicolumn{8}{|l|}{$\min ^{-1} \times 1.000$} \\
\hline$l_{l, l l}$ & $55.2 \pm 13.0$ & $67.0 \pm 16.7$ & $61.1 \pm 12.5$ & $30.9 \pm 9.2$ & $76.6 \pm 12.3$ & $70.6 \pm 50.4$ & $58.2 \pm 15.4$ \\
\hline$l_{V, I c}$ & $48.7 \pm 7.2$ & $62.1 \pm 9.2$ & $57.7 \pm 4.7$ & $57.2 \pm 4.8$ & $41.8 \pm 3.9$ & $73.6 \pm 28.0$ & $53.5 \pm 7.3$ \\
\hline$l_{l s, l c}$ & $24.4 \pm 2.6$ & $41.5 \pm 2.8$ & $20.1 \pm 3.8$ & $37.3 \pm 2.0$ & $40.3 \pm 3.8$ & $40.0 \pm 6.0$ & $32.7 \pm 8.8$ \\
\hline$l_{l c, l s}$ & $3.9 \pm 0.7$ & $3.7 \pm 0.5$ & $6.8 \pm 1.0$ & $3.7 \pm 0.3$ & $5.1 \pm 0.6$ & $4.7 \pm 1.4$ & $4.6 \pm 1.2$ \\
\hline$l_{p r, l s}$ & $1.4 \pm 0.6$ & $2.9 \pm 0.4$ & $1.2 \pm 1.3$ & $3.6 \pm 0.4$ & $3.7 \pm 0.5$ & $3.2 \pm 1.2$ & $2.6 \pm 1.1$ \\
\hline$l_{m c, l f}$ & $5.8 \pm 0.8$ & $10.2 \pm 1.3$ & $5: 4 \pm 0.9$ & $9.9 \pm 2.2$ & $10.2 \pm 1.1$ & $9.0 \pm 2.8$ & $8.3 \pm 2.2$ \\
\hline$l_{P r, l l}$ & $10.4 \pm 2.7$ & $10.8 \pm 3.8$ & $20.0 \pm 2.4$ & $4.4 \pm 2.9$ & $10.1 \pm 2.1$ & $10.9 \pm 9.8$ & $7.5 \pm 3.6$ \\
\hline$l_{Y, l o}$ & $83.6 \pm 18.3$ & $106.0 \pm 19.5$ & $140.0 \pm 13.8$ & $593.0 \pm 144.0$ & $134.0 \pm 21.6$ & $81.8 \pm 35.3$ & $211.3 \pm 191.9$ \\
\hline$l_{b s, m c}$ & $59.3 \pm 12.5$ & $153.0 \pm 37.4$ & $8,200 \pm 156,000$ & $277.0 \pm 59.0$ & $1,200.0 \pm 580.0$ & $294.0 \pm 338.0$ & $1,977.9 \pm 3137.6$ \\
\hline$l_{b, m c}$ & $84.3 \pm 21.0$ & $88.8 \pm 24.6$ & $34,400 \pm 672,000$ & $146.0 \pm 29.3$ & $721.0 \pm 353.0$ & $182.0 \pm 227.0$ & $7,088.0 \pm 13,658.1$ \\
\hline$l_{b, b c}$ & $1,000.0 \pm 80.7$ & $283.0 \pm 40.2$ & $376.0 \pm 340.0$ & $714.0 \pm 71.9$ & $792.0 \pm 300.0$ & $667.0 \pm 142.0$ & $243.3 \pm 134.4$ \\
\hline$l_{b c c, b f}$ & $145.0 \pm 7.5$ & $91.5 \pm 6.4$ & $439.0 \pm 158.0$ & $176.0 \pm 17.2$ & $365.0 \pm 50.4$ & $256.0 \pm 48.0$ & $143.4 \pm 81.1$ \\
\hline$l_{b s, b c}$ & $108.0 \pm 16.2$ & $17.0 \pm 6.5$ & $147.0 \pm 83.5$ & $262.0 \pm 66.0$ & $183.0 \pm 68.5$ & $243.0 \pm 99.2$ & $633.0 \pm 266.5$ \\
\hline$l_{b s, b s}$ & $13.1 \pm 1.1$ & $19.9 \pm 2.2$ & $54.0 \pm 6.5$ & $28.2 \pm 1.9$ & $33.3 \pm 2.5$ & $38.5 \pm 3.7$ & $29.7 \pm 14.0$ \\
\hline$l_{\text {loss }, b c}$ & $14.5 \pm 2.4$ & $28.6 \pm 3.3$ & $17.7 \pm 7.6$ & $55.1 \pm 8.0$ & $40.8 \pm 12.7$ & $37.7 \pm 11.9$ & $31.3 \pm 15.0$ \\
\hline$l_{b, b c}$ & $167.0 \pm 18.0$ & $48.0 \pm 6.7$ & $48.0 \pm 23.6$ & $168.2 \pm 37.1$ & $78.7 \pm 27.4$ & $108.0 \pm 44.9$ & $102.0 \pm 54.7$ \\
\hline$k_{l c}$ & $5.3 \pm 0.4$ & $5.2 \pm 0.4$ & $2.4 \pm 0.1$ & $4.5 \pm 0.3$ & $8.9 \pm 0.6$ & $5.3 \pm 1.3$ & $5.2 \pm 2.1$ \\
\hline
\end{tabular}

Abbreviations are defined in Fig. 4 with exceptions of $P r=$ protein and $k_{k}$, which is the fraction of the total pool that is contained in $1 \mathrm{ml}$ plasma. Cav values were obtained from analysis of averaged curves. Mean values are the average of the values from $C_{1}$ to $C_{5}$. Subscripts follow the "to, from" convention.

Labeled $\mathrm{CO}_{2}$, which entered the metabolic carbon pool $(m c)$, was partitioned between direct transfer to breath (compartment $b$ ) and passage into one of the peripheral bicarbonate $/ \mathrm{CO}_{2} /$ metabolic carbon pools (compartment $b s$ ), i.e., $38 \%$ of labeled carbon was shunted directly to breath without equilibrating with whole body bicarbonate stores (compartments $b f, b c, b s$ ).

The values provided above for transport and metabolism of tracer lysine were applicable also to endogenous lysine, with the exception that endogenous lysine was introduced continuously into compartments $l f$ and $l s$ by protein breakdown.

Protein breakdown and synthesis rates. Lysine input, as a result of protein breakdown into the peripheral compartments lf and $l s$, was indeterminable from the data collected in this study. The lysine compartmental model, however, provided a linear correlation between net protein lysine balance in compartments $l f$ and $l s$ and overall whole body lysine flux, as well as boundary conditions. The first boundary condition is the absence of protein breakdown in compartment $l s$ (Fig. 6). This would have resulted in a net protein lysine loss of $61.1 \mu \mathrm{mol} /$ $\mathrm{kg} / \mathrm{min}$ in compartment lf, a net protein lysine gain of 37.0 $\mu \mathrm{mol} / \mathrm{kg} / \mathrm{min}$ in compartment $l s$, lysine oxidation rate of 24.2 $\mu \mathrm{mol} / \mathrm{kg} / \mathrm{min}$, and an overall whole body lysine flux of 91.2 $\mu \mathrm{mol} / \mathrm{kg} / \mathrm{min}$. As we move away from this boundary condition, an increase in protein breakdown in compartment $l s$ would have been associated with a decrease in breakdown in compartment $l s$, accompanied by an increase in whole body lysine flux. If protein breakdown had equaled protein synthesis in compartment $l s$, as in the calculation of the steady-state values given above, whole body lysine flux would have been $106.4 \mu \mathrm{mol} / \mathrm{kg} /$ $\min$. At the second boundary condition in which no protein breakdown occurred in compartment $l s$, a maximum whole body lysine flux of $119.2 \mu \mathrm{mol} / \mathrm{kg} / \mathrm{min}$ would have been achieved.
Fig. 6 also demonstrates that an independent estimate of whole-body flux, such as that obtained from continuous infusion measurements, could be used to provide a unique estimate of protein balance in both compartments $l f$ and $l s$ when used in conjunction with the lysine multicompartmental model.

\section{Discussion}

Multicompartmental analysis of lysine kinetics in humans has shown that it is possible to partition whole-body protein synthesis and breakdown into processes occurring in two compartments distinguished by their respective rates of lysine exchange with the central compartment. The potential importance of such a model is that it could be used to measure the depletion and repletion of muscle and visceral protein stores and changes in the levels of free amino acid pools under a variety of nutritional, metabolic, and pathophysiologic conditions. The utility of the lysine compartmental model depends on the extent to which the mathematical compartments can be assigned to metabolic or anatomic entities and also on the agreement of the wholebody kinetic parameters, derived from the compartmental model, with those previously obtained by constant infusion measurements of amino acid flux and oxidation.

Multicompartmental analysis revealed three distinct lysine pools. The central pool of which plasma is a part had a volume of $\sim 227 \mathrm{ml} / \mathrm{kg}$, which suggests that it consists primarily of free lysine in extracellular fluids. Lysine in intracellular spaces must therefore contribute to the two peripheral pools. Tissues which have similar rates of exchange of intracellular lysine with extracellular lysine would be "lumped" into the same peripheral pool. The kinetic characteristic of each of the "lumped" peripheral 
Table VIII. Multicompartmental Kinetic Parameters for the Lysine and Bicarbonate Systems

\begin{tabular}{|c|c|c|c|c|c|c|c|}
\hline \multirow[b]{2}{*}{ Parameter } & \multicolumn{7}{|l|}{ Subjects } \\
\hline & $\mathrm{Cl}$ & $\mathrm{C} 2$ & $\mathrm{C} 3$ & $\mathrm{C} 4$ & C5 & Cav & Mean \\
\hline \multicolumn{8}{|c|}{ Lysine pool sizes $\mu \mathrm{mol} / \mathrm{kg}$} \\
\hline$M_{l f}$ & $64.6 \pm 8.4$ & $31.8 \pm 3.8$ & $62.9 \pm 9.4$ & $26.1 \pm 6.3$ & $44.4 \pm 4.9$ & $37.1 \pm 11.5$ & $46.0 \pm 15.7$ \\
\hline$M_{l c}$ & $54.6 \pm 3.8$ & $29.2 \pm 2.3$ & $59.3 \pm 3.0$ & $48.6 \pm 3.4$ & $24.2 \pm 1.7$ & $38.5 \pm 8.9$ & $43.2 \pm 14.0$ \\
\hline$M_{l s}$ & $318 \pm 111$ & $331 \pm 66$ & $175 \pm 51$ & $496 \pm 45$ & $190 \pm 32$ & $324 \pm 152$ & $302 \pm 116$ \\
\hline \multicolumn{8}{|c|}{$\begin{array}{l}\text { Bicarbonate pool sizes, } \\
\qquad \mu \mathrm{mol} / \mathrm{kg}\end{array}$} \\
\hline$M_{b f}$ & $7,366 \pm 368$ & $12,777 \pm 639$ & $2,814 \pm 732$ & $4,074 \pm 448$ & $4,116 \pm 329$ & $3,700 \pm 481$ & $6,229 \pm 3604$ \\
\hline$M_{b c}$ & $2,929 \pm 351$ & $3,287 \pm 427$ & $2,714 \pm 1411$ & $716 \pm 136$ & $1,651 \pm 677$ & $1,157 \pm 579$ & $2,259 \pm 945$ \\
\hline$M_{b s}$ & $7,735 \pm 464$ & $2,732 \pm 574$ & $7,535 \pm 603$ & $6,699 \pm 402$ & $9,057 \pm 362$ & $7,864 \pm 393$ & $6,752 \pm 2147$ \\
\hline
\end{tabular}

Transfer rates,

$\mu \mathrm{mol} / \mathrm{kg} / \mathrm{min}$

Lysine distribution rates

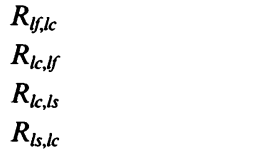

Lysine incorporation into protein

$$
\begin{aligned}
& R_{P r, l f} \\
& R_{P r, l s}
\end{aligned}
$$

Lysine oxidation

$$
R_{m c, l f}
$$

$3.30 \pm 0.59$

$3.30 \pm 0.59$

$1.30 \pm 0.20$

$1.30 \pm 0.20$

$1.95 \pm 0.37$
$1.95 \pm 0.37$
$1.21 \pm 0.12$
$1.21 \pm 0.12$

$3.63 \pm 0.51$

$3.63 \pm 0.51$

$1.19 \pm 0.23$

$1.19 \pm 0.23$

$1.49 \pm 0.37$

$1.49 \pm 0.37$

$1.81 \pm 0.13$

$1.81 \pm 0.13$

$1.87 \pm 0.21$

$0.98 \pm 0.11$

$0.98 \pm 0.11$

$2.72 \pm 1.36$

$2.72 \pm 1.36$

$1.54 \pm 0.37$

$1.54 \pm 0.37$

$2.45 \pm 0.85$

$2.45 \pm 0.85$

$1.30 \pm 0.28$

$1.30 \pm 0.28$

$0.730 \pm 0.234$

$0.380 \pm 0.304$

$0.336 \pm 0.144$

$1.250 \pm 0.263$

$0.113 \pm 0.110$

$0.942 \pm 0.283$

$0.214 \pm 0.255$

$1.820 \pm 0.273$

$0.457 \pm 0.123$

$0.698 \pm 0.202$

$0.409 \pm 0.429$

$1.030 \pm 0.803$

$0.577 \pm 0.391$

$0.811 \pm 0.564$

$0.370 \pm 0.007$

$0.322 \pm 0.006$

$0.336 \pm 0.007$

$0.260 \pm 0.008$

$0.453 \pm 0.009$

$0.335 \pm 0.017$

$0.348 \pm 0.063$

Metabolic carbon partitioning

$R_{b s, m c}$

$R_{b, m c}$

$0.157 \pm 0.009$

$0.203 \pm 0.010$

$0.065 \pm 0.012$

$0.170 \pm 0.009$

$0.283 \pm 0.014$

$0.207 \pm 0.023$

$0.128 \pm 0.015$

$0.176 \pm 0.071$

$0.273 \pm 0.011$

$0.090 \pm 0.005$

$0.170 \pm 0.010$

Bicarbonate distribution and elimination

$R_{b c, b f}$

$R_{b f, b c}$

$R_{b, b c}$

$R_{\text {loss }, b c}$

Inputs, $\mu \mathrm{mol} / \mathrm{kg} / \mathrm{min}$

Protein breakdown

$$
U_{l s}
$$

$U_{l s}$

$0.379 \pm 0.303$

$1.100 \pm 0.231$

$0.942 \pm 0.283 \quad 0.214 \pm 0.255$

$1.820 \pm 0.273$

$0.700 \pm 0.203$

$0.372 \pm 0.112$

$0.910 \pm 0.127$

$1.030 \pm 0.803$

$0.811 \pm 0.564$

$0.659 \pm 0.145 \quad 1.590 \pm 0.270$

$164 \pm 3$

$196 \pm 4$

$0.744 \pm 0.439$

$0.926 \pm 0.412$

$182 \pm 2$

$248 \pm 5$

$181 \pm 5$

$180 \pm 7$

$194 \pm 29$

Derived parameters

Half-life in Comp O $(\mathrm{min})$

Systemic availability

Vol of $l c\left(\mathrm{ml} \cdot \mathrm{kg}^{-1}\right)$

Oxidation/protein synthesis (\%)

Whole body flux

$(\mu \mathrm{mol} / \mathrm{kg} / \mathrm{min})$
$8.86 \pm 1.68$

$0.749 \pm 0.015$

$185 \pm 13$

$6.52 \pm 1.30$

$0.748 \pm 0.015$

$4.96 \pm 0.55$

$1.17 \pm 0.27$

$0.800 \pm 0.016$

$223 \pm 16$

$424 \pm 21$

$25.1 \pm 2.0$

$20.1 \pm 1.8$

$18.7 \pm 0.4$

$11.8 \pm 1.1$

$1.49 \pm 0.12$

$1.60 \pm 0.14$

$1.80 \pm 0.04$

$2.19 \pm 0.15$
$5.23 \pm 0.89$

$0.673 \pm 0.013$

$112 \pm 8$

$28.2 \pm 1.7$

$1.61 \pm 0.08$
$8.49 \pm 3.57$

$0.785 \pm 0.039$

$188 \pm 43$

$18.9 \pm 4.3$

$1.77 \pm 0.37$
$5.35 \pm 2.50$

$0.733 \pm 0.045$

$227 \pm 105$

$20.8 \pm 5.2$

$1.74 \pm 0.25$

$M, R$, and $U$ refer to mass, transfer rates, and input rates. Subscripts are defined in Fig. 3. 


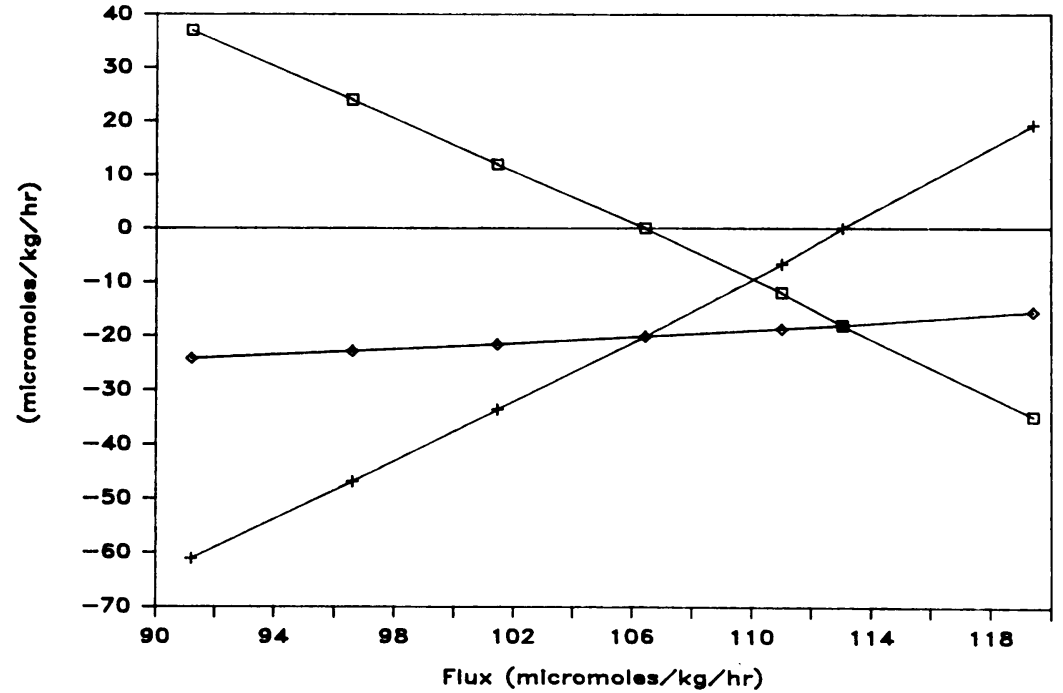

Figure 6. Correlation between the calculated values of the difference between lysine incorporation into protein and release by protein breakdown for splanchnic (+) and muscle ( $\square$ ) tissues vs. overall whole-body lysine flux. The difference between net lysine uptake at one site and net lysine release at another is accounted for by lysine oxidation $(\diamond)$. The curve demonstrates how the partitioning of protein balance can be determined when an independent estimate of whole-body lysine flux is available. pools would be determined by that of its major constituent. The slow-exchanging pool contained approximately $300 \mu \mathrm{mol} / \mathrm{kg}$ free lysine and accounted for $61 \%$ of total whole-body protein synthesis. These values are in reasonable agreement with those reported for muscle. Assuming muscle is $40 \%$ of body mass, there are $400 \mathrm{~g}$ of muscle (per kilogram of body weight) containing $267 \mathrm{ml}$ of intracellular water with a free lysine concentration of

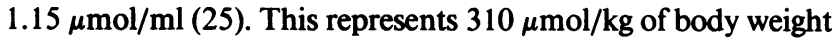
of free intracellular lysine, which corresponds exactly to the size of the slow-exchange compartment. The contribution of muscle to whole body protein synthesis has been reported to be $\sim 50 \%$ by Halliday and McKeran (6) and Rennie et al. (26) who carried out continuous $\left[{ }^{15} \mathrm{~N}\right]$ lysine and $\left[{ }^{13} \mathrm{C}\right]$ leucine infusions with serial muscle biopsies in healthy adult male subjects. These results are in agreement with the value obtained for the slow-exchange compartment. Assigning the slow-exchange compartment to tissues with kinetics that are characteristic of muscle, leaves the assignment of the fast-exchange compartment to tissues with kinetics that are characteristic of viscera. This assignment is consistent with the path of orally administered tracer passing through the fast-exchange compartment before mixing with the central extracellular pool and with the fast-exchange compartment being the primary site of lysine oxidation. Definitive assignment of the fast- and slow-exchanging pools to "viscera" and "muscle" will require a similar multitracer experiment with repetitive plasma and breath sampling and serial tissue biopsies in human subjects or in animals with similar lysine kinetics.

Comparisons of multicompartmental kinetic parameters with those derived by stochastic methods are complicated by the fact that all previously reported kinetic parameters have been obtained in male subjects, whereas the present study is the first report of lysine kinetics in female volunteers. Moreover, lysine kinetics have been measured previously in either the overnightfasted state or the continuously fed state in subjects maintained on either high $(1.5 \mathrm{mg} / \mathrm{kg} / \mathrm{d})$ or low $(0.4 \mathrm{~g} / \mathrm{kg} /$ day $)$ protein intakes, or on either adequate $(20 \mu \mathrm{mol} / \mathrm{kg} / \mathrm{h})$ or lysine-free intakes. In the present study, lysine kinetic measurements were made during the 4- to 10-h postprandial period on subjects who had been maintained on slightly more than adequate lysine intakes (1.1 $\mathrm{g} / \mathrm{kg} /$ day protein and $86 \mathrm{mg} / \mathrm{kg} /$ day lysine). The most extensive set of determinations of lysine whole body flux carried out in humans over a wide range of lysine dietary intakes was reported recently by Meredith et al. (27). Interpolation of their data to a dietary lysine intake of $86 \mathrm{mg} / \mathrm{kg} / \mathrm{d}$ yields a lysine flux of $\sim 120$ $\mu \mathrm{mol} / \mathrm{kg} / \mathrm{h}$ and a lysine oxidation rate of $\sim 23 \mu \mathrm{mol} / \mathrm{kg} / \mathrm{h}$ for the fed state. Conway et al. (28) have reported lysine flux of 93 and $84 \mu \mathrm{mol} / \mathrm{kg} / \mathrm{h}$ for subjects on adequate intakes in the fed and fasted states, respectively, and fed and fasted flux values of 107 and $97 \mu \mathrm{mol} / \mathrm{kg} / \mathrm{h}$ for subjects on higher intakes. Motil et al. (29) reported postabsorptive and fed-state values of lysine flux of 119 and $101 \mu \mathrm{mol} / \mathrm{kg} / \mathrm{min}$, respectively, for subjects on $1.5 \mathrm{~g} / \mathrm{kg} / \mathrm{d}$ protein intakes and lysine flux values of 86 and 87 $\mu \mathrm{mol} / \mathrm{kg} / \mathrm{d}$, respectively, for subjects on $0.6 \mathrm{~g} / \mathrm{kg} / \mathrm{d}$ protein intakes. Earlier studies reported values of 105 (17) and 74 (18) $\mu \mathrm{mol} / \mathrm{kg} / \mathrm{d}$. The results obtained by multicompartmental analysis in the present study are in good agreement with these values. In an analysis of the set of averaged curves, lysine flux ranged from 91 to $119 \mu \mathrm{mol} / \mathrm{kg} / \mathrm{min}$, depending on the partitioning of protein breakdown between body pools, and had a value of approximately $105 \mu \mathrm{mol} / \mathrm{kg} / \mathrm{min}$ which was near the physiologically relevant condition of negative protein balance in the visceral compartment and almost balanced synthesis and breakdown in the peripheral compartment. For the same set of conditions, the multicompartmental value of lysine oxidation ranged from 15 to $25 \mu \mathrm{mol} / \mathrm{kg} / \mathrm{h}$, in excellent agreement with the reported value (27). The mean plasma lysine level of $204 \mu \mathrm{mol} / \mathrm{liter}$ also was in agreement with the values reported by Meredith et al. (27), interpolated to a lysine intake value of $85 \mathrm{mg} / \mathrm{kg} / \mathrm{d}$.

Multicompartmental analysis provides many types of pool size and transfer rate data that can be subjected subsequently to exhaustive correlation analysis. Such a statistical analysis is beyond the scope of this paper, but one trend in the data seems worthy of mention. The absolute rate of lysine oxidation does not appear to be dependent on the free lysine level in the visceral compartment. The rates of both protein synthesis and breakdown, however, seem to increase as the free lysine level in the compartment increases. Furthermore, the subject with the highest visceral lysine pool had the smallest muscle lysine pool and vice versa. Multicompartmental kinetic data have the potential to provide insights into the relationship between the size of free amino acid pools and the absolute rates of protein synthesis and breakdown, as well as into the relationship between changes in free amino acid pools in various body compartments.

In this study, kinetic analysis was carried out on plasma and 
breath tracer levels achieved after the input bolus of tracer lysines. During the multicompartmental analysis of these data, a great potential synergy between bolus input and continuous infusion kinetic data became apparent. The exact partitioning of protein synthesis and breakdown between visceral and muscle compartments was indeterminable when only bolus input data were analyzed. Simulation calculations, however, indicated that when an independent estimate of whole-body lysine flux, such as that obtained from the primed constant-infusion method (30), was combined with the bolus input-response data, the partitioning of protein synthesis and breakdown between visceral and muscle compartments could be fixed. From future studies that utilize primed constant infusion and bolus i.v. injections of various forms of stable isotope-labeled lysine, it should be possible to determine whether the lysine multicompartment kinetic model correctly predicts the expected changes in protein balance in the viscera and muscle on going from the fasted to the fed state.

\section{Acknowledgments}

We are indebted to Tina McClellan, Becky Hethcock, and Kim Evans for nursing support, to E. R. Klein for editorial supervision of this manuscript, and to Sheri Wahl and Sandy Perez for manuscript preparation.

This work was supported by the U. S. Department of Agriculture/ Agricultural Research Service Children's Nutrition Research Center, the Department of Pediatrics, Baylor College of Medicine, Texas Children's Hospital, and by grant AM-28129 from the National Institutes of Health.

\section{References}

1. Young, V. R., R. D. Yang, C. Meredith, D. E. Matthews, and D. M. Bier. 1983. Modulation of amino acid metabolism by protein and energy intakes. In Amino Acids Metabolism and Medical Application. G. L. Blackburn, J. P. Grant, and V. R. Young, editors. John Wright PSG, Inc., Littleton, MA. 13-28.

2. Waterlow, J. C., P. J. Garlick, and D. J. Millward. 1978. Protein Turnover in Mammalian Tissues and in the Whole Body. North-Holland Publishing Company, Amsterdam.

3. Garlick, P. J., D. J. Millward, and W. P. T. James. 1973. Diurnal response of muscle and liver protein synthesis in vivo in meal-fed rats. Biochem. J. 136:935-945.

4. Garlick, P. J., M. A. Nurland, and V. R. Preedy. 1980. A rapid and convenient method for measuring the rate of protein synthesis in tissues by injection of $\left[{ }^{3} \mathrm{H}\right]$-phenylalanine. Biochem. J. 192:719-723.

5. Elwyn, D. H., H. C. Parikh, and W. C. Shoemaker. 1968. Amino acid movements between gut, liver and periphery in unanesthetized dogs. Am. J. Physiol. 226:1428-1433.

6. Halliday, D., and R. O. McKeran. 1975. Measurement of muscle protein synthetic rate from serial muscle biopsies and total protein turnover in man by continuous intravenous infusion of $\mathrm{L}-\left[\alpha-{ }^{15} \mathrm{~N}\right] \mathrm{lysine}$. Clin. Sci. Mol. Med. 49:581-590.

7. Aoki, T. T., M. F. Brennan, W. A. Muller, J. S. Soeldner, J. S. Alpert, S. B. Saltz, R. L. Kaufmann, M. H. Tan, and G. F. Cahill. 1976. Amino acid levels across normal forearm muscle and splanchnic bed after a protein meal. Am. J. Clin. Nutr. 29:340-350.

8. Wahren, J., P. Felig, and L. Hagenfeldt. 1976. Effect of protein ingestion on splanchnic and leg metabolism in normal man and in patients with diabetes mellitus. J. Clin. Invest. 57:987-999.

9. Matthews, D. E., K. J. Motil, D. K. Rohrbaugh, J. F. Burke, V. R. Young, and D. M. Bier. 1980. Measurement of leucine metabolism in man from a primed, continuous infusion of $\mathrm{L}-\left[1-{ }^{13} \mathrm{C}\right]$ leucine. $A m . J$. Physiol. 238(Endocrinol. Metab. 1):E473-E479.

10. Irving, C. S., C. L. Cooney, L. T. Brown, D. Gold, J. Gordon, and P. D. Klein. 1983. Microbial fermentative preparation of $\mathrm{L}-\mathrm{di}-{ }^{15} \mathrm{~N}$ lysine and its application to serum amino acid kinetic studies. Anal. Biochem. 131:93-98.

11. Klein, P. D. 1982. Clinical applications of ${ }^{13} \mathrm{CO}_{2}$ measurements. Fed. Proc. 41:84-87.

12. The National Research Council. 1980. Recommended Dietary Allowances. National Academy of Sciences, Washington, D. C.

13. Irving, C. S., W. W. Wong, R. J. Shulman, E. O. Smith, and P. D. Klein. $1983 .{ }^{13} \mathrm{C}$ bicarbinate kinetics in man: intra vs interindividual differences. Am. J. Physiol. 245:R190-202.

14. Schoeller, D. A., and P. D. Klein. 1979. A microprocessor controlled mass spectrometer for the fully automated purification and isotopic analysis of breath $\mathrm{CO}_{2}$. Biomed. Mass Spectrom. 6:350-355.

15. Hachey, D. L., J.-C. Blais, and P. D. Klein. 1980. High precision isotopic ratio of analysis of volatile metal chelates. Anal. Chem. 52:11311135.

16. Irving, C. S., D. A. Schoeller, K.-I. Nakamura, A. L. Baker, and P. D. Klein. 1982. The aminopyrine breath test as a measure of liver function: a quantitative description of its metabolic basis in normal subjects. J. Lab. Clin. Med. 100:356-373.

17. Segal, G. B., W. Simon, and M. A. Lichtman. 1983. A multicomponent analysis of amino acid transport systems in human lymphocytes. 1. Kinetic parameters of the $A$ and $L$ systems and pathways of uptake of naturally occurring amino acids in blood lymphocytes. $J$. Cell. Physiol. 116:372-378.

18. Elwyn, D. 1970. The role of liver in regulation of amino acid and protein metabolism. In Mammalian Protein Metabolism. Vol. 4. H. Munro, ed. Academic Press, Inc., New York. 523-556.

19. DiStefano, J. J. III, and E. M. Landaw. 1984. Multiexponential, multicompartmental, and noncompartmental modeling. I. Methodological limitations and physiological interpretations. Am. J. Physiol. 246(Regul. Integrat. Comp. Physiol. 15):R651-R664.

20. Aub, M. B., and J. C. Waterlow. 1970. Analysis of a five compartment system with continuous infusion and its application to the study of amino acid turnover. J. Theor. Biol. 26:243-250.

21. Cobelli, C., A. Pepschy, and G. R. Jacur. 1980. Identifiability in tracer experiments. Fed. Proc. 39:91-96.

22. Cobelli, C., and J. J. DiStefano, III. 1980. Parameter and structural identifiability concepts and ambiguities: a critical review and analysis. Am. J. Physiol. 239(Regul. Integrat. Comp. Physiol. 8):R7-R24.

23. Yang, R. D., C. S. Irving, W. W. Wong, J. H. Hoffer, V. R. Young, and P. D. Klein. 1983. The effect of diet and meal ingestion on whole body ${ }^{13} \mathrm{C}$-bicarbonate kinetics in young men. Fed. Proc. 42:825. (Abstr.)

24. Berman, M., and M. F. Weiss. 1978. SAAM Manual, U. S. DHEW Pub. No. (NIH) 78-180.

25. Vinnar, E., J. Bergstom, and P. Furst. 1976. Influence of the postoperative state on the intracellular free amino acids in human muscle tissue. Ann. Surg. 182:665-671.

26. Rennie, M. J., R. H. T. Edwards, D. Halliday, D. E. Matthews, S. L. Wolman, and D. J. Millward. 1982. Muscle protein synthesis measured by stable isotope techniques in man: the effects of feeding and fasting. Clin. Sci. (Lond.). 63:519-523.

27. Meredith, C. N., Z-M Wen, D. M. Bier, D. Matthews, and V. R. Young. 1985. Whole body lysine metabolism in young men at graded levels of dietary lysine. Am. J. Clin. Nutr. In press.

28. Conway, J. C., D. M. Bier, K. J. Motil, J. F. Burke, and V. R. Young. 1980. Whole body lysine flux in young adult men: effects of reduced total protein and of lysine intake. Am. J. Physiol. 239(Endocrinol. Metab. 2):E192-E200.

29. Motil, K. J., D. E. Matthews, D. M. Bier, J. F. Burke, H. N. Munro, and V. R. Young. 1981. Whole body leucine and lysine metabolism: response to dietary protein intake in young men. Am. J. Physiol. 240(Endrocrinol. Metab. 2):E712-721.

30. Waterlow, J. C. 1967. Lysine turnover in man measured by intravenous infusion of $\mathrm{L}-\left[\mathrm{U}-{ }^{14} \mathrm{C}\right]$ lysine. Clin. Sci. (Oxf.). 33:507-515. 